\title{
The Normal Body - Anthropology of Bodily Otherness
}

\author{
Henning Eichberg
}

University of Southern Denmark

KEYWORDS

Human biology and medical science focus on the normality of the human body. This focus deserves, however, to be questioned. Cultural studies, in contrast, focus on normalities in plural - normalities of diverse cultures, revealed by comparison and under the historical perspective of change. The normality and otherness of bodily ageing delivers pictures for this analytical problem, among these the figure of the shaman, the elderly as healer.

Normality is connected with power. That is why the cultural analysis of normalization can be connected with the theory of democracy, especially with the understanding of human sovereignty and equality, otherness and recognition.

Likewise, the theory of sports as a field of trialectic tensions opens up concrete, bodily differences. The body of the Japanese sumo wrestler delivers a living picture of how to relate to bodily otherness. This leads to a deeper understanding of the politics of recognition and of bodily relativity. Additionaly, normality in terms of biology and normalities in terms of cultural studies need to be confronted within a critical dialogue.

body culture, ageing, otherness, shamanism, bodily democracy, sumo

What is the normality of the body, and how is this normality related to the bodily diversity of living human beings? What significance do normality and otherness have for body politics?

We live with an archetypical imagination of normality in our mind, which is deeply rooted in our culture. It was expressed - as an aesthetical design - during the European Renaissance by Leonardo da Vinci (Figure 1).

Science is not independent of this imagination. The inner image of normality strongly influences human biology and medical science - with their focus on the normal human body - under the perspective of practical therapy as normalization. Demands for statistical representation are a way of generalizing and linking them to 'the normal'. The Western 'archetype', which is neither elderly nor disabled, must also be kept in mind.

\section{Questioning the normal body of biology}

There are, however, reasons to question the normality of body. One of the most urgent reasons for this critical approach is the ageing of the body (Povlsen 2000).

From the biological and medical perspectives, one typically describes normal human ageing. Normalization is found in gerontology as the most obvious approach, helping to design interventions of rehabilitation as routes back to normality. Let us make or keep the aged body young and fit. 


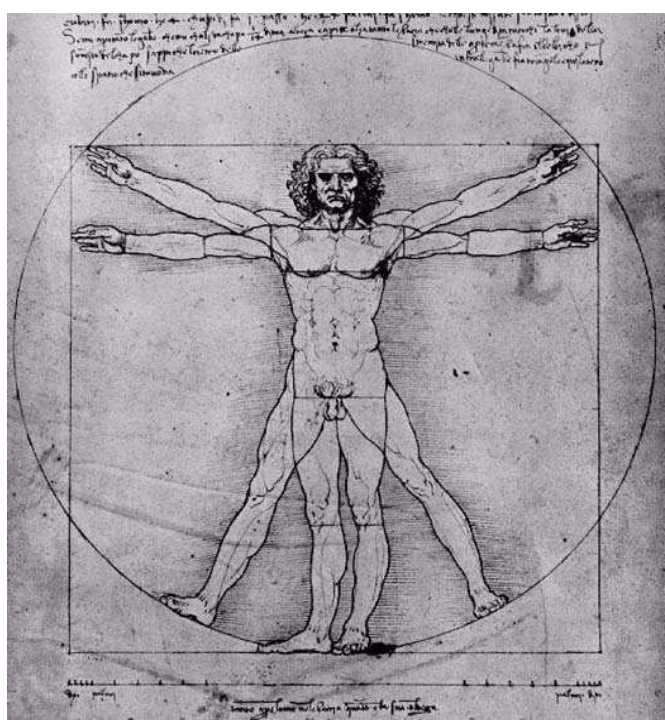

Figure1. Leonardo da Vinci: Homo vitruvianus Source: http://da. wikipedia.org/wiki/Leonardo_ da_Vinci.
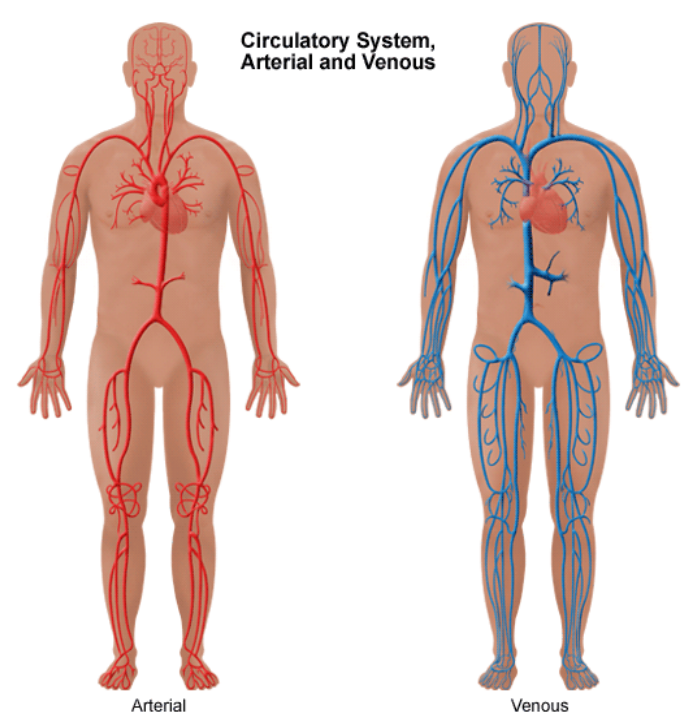

Figure 2. The circulatory system

Source: Yale Medical Group. http://www.yale medicalgroup.org.

In the scientific images produced for this purpose, one finds the Western 'archetypical' pattern again (Figure 2).

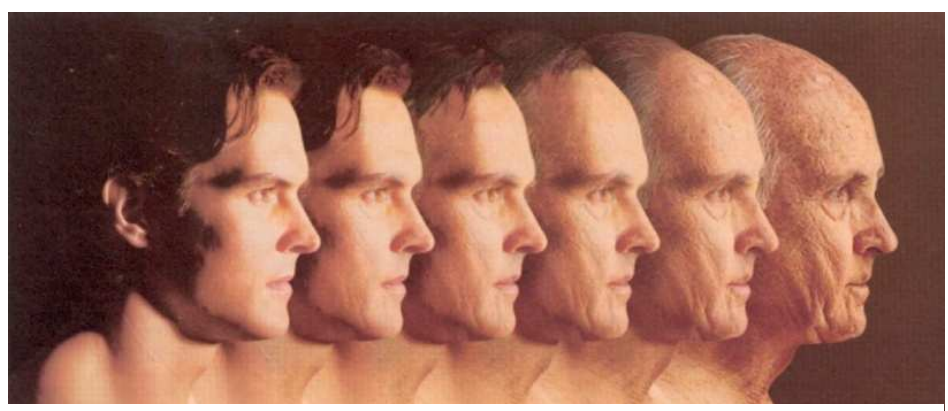

Figure 3. Ageing as change of organism Source: http://4.bp.blogspot.com.
And in a developmental time sequence (Figure 3).

Normalization, however, is not only a question of images but also of bodily-social practice. Fitness activities are designed to re-establish the normal body.

However, we may be bewildered when meeting the body of old body builders. (One of them, here in the middle, is in his nineties). Ageing also produces otherness.

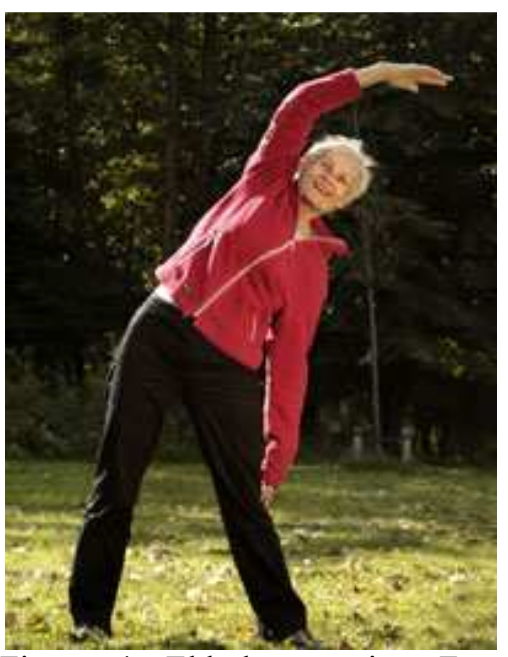

Figure 4. Elderly exercise. From: Senor Comfort Guide Blog

Source: Senor Comfort Guide Blog; http://www.seniorcareservicesblog. com.

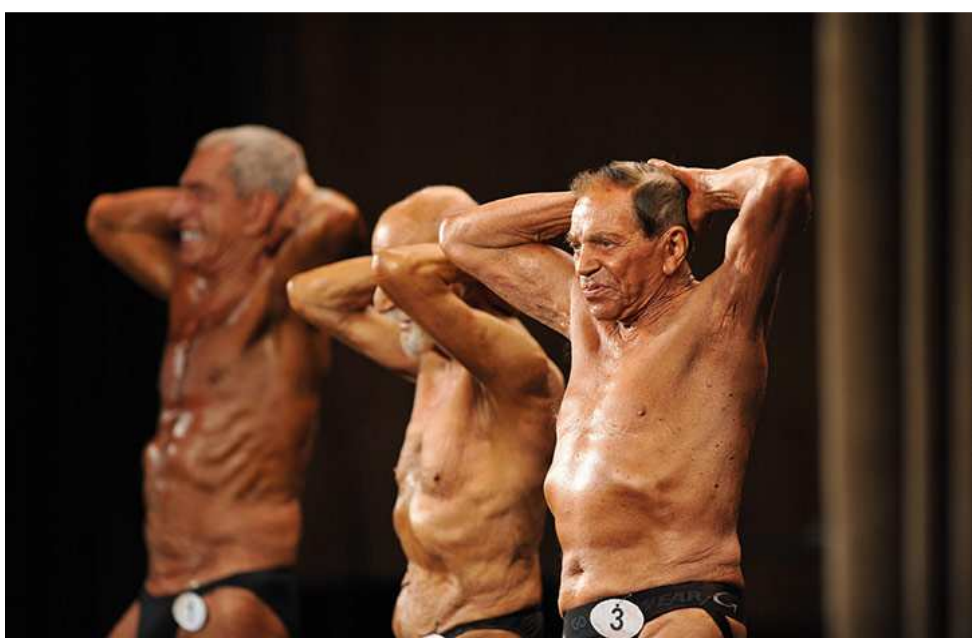

Figure 5. Senior bodybuilding

Source: Senor Comfort Guide Blog; http://www.seniorcareservice sblog.com. 
Here, we approach the limits of biological normality.

However, also biology knows about distinct normalities of the ageing body. Maybe the most

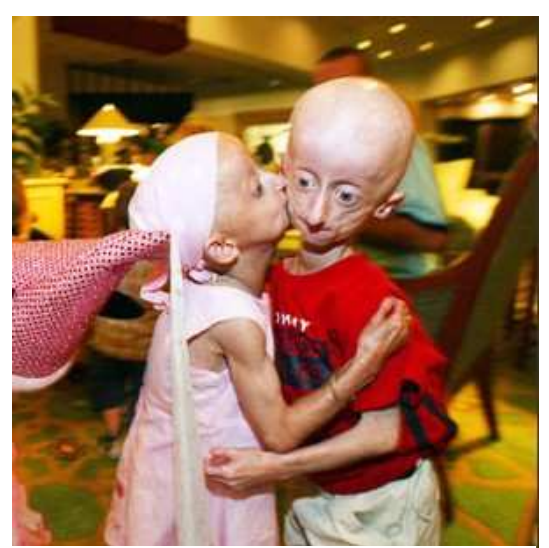

Figure 6. Progeria

Source: http://www.pharmainfo.net. extreme 'other' phenomenon of ageing is progeria, the disease of accelerated ageing (Figure 6).

As a disease, progeria is regarded as an abnormal phenomenon. But it has a certain - though statistically rare normality, too. It is this particular normality of progeria that makes families with progeria join together all over the world in client organizations. Through self-organization, people build normality inside abnormality - another normality. In other words, Normality becomes a question of plural: normalities (About the comprehensive problem of disability and physical activity see Jespersen, McNamee 2008).

\section{The other normalities of cultures}

Our perspective here, however, will be of a non-biological character: questioning the normality of the cultural body by turning to the plurality of body cultures (Eichberg 2010). Many cultures in the world - especially in the far north (Siberia, Inuit, Saami), in Central and East Asia (Korea, Indonesia) and among Native Americans - have for instance developed a particular social figure to represent the elderly phase of life: the shaman, the medicine man or medicine woman.

A case in point is the shaman of the Mentawai people, living on islands found on the western coast of West Sumatra (Lindsay, Schefold 1992). Here, elderly people will experience ageing as the challenge to become a spiritual healer. After a life of work, of family care and power play, the human being may be hit, often following a serious illness, by a sudden 'vocation' to become 'another'. What happens to the elderly person is a fundamental shift of track. From now on, one will be able to 'hear' the spirits and to 'talk' to the souls. The human being mature in life years can contribute something to society that none of the younger people can.

The elder person thus experiences - or creates - innovation. The alternative is not, like in Western modernity, either retirement or continuation, but a new status in society. The turn towards becoming a shaman and practicing shamanism has a very bodily character. The shaman's body is dressed and decorated in a new, eccentric way, and it also moves in new ways. Shamanic practice consists of dance and drumming, of techniques of trance and ecstasy. The shaman is the artist of the tribe. The spiritual healers are free - and expected - to do superfluous and creative things. They may take themselves un-seriously, play the fool and display themselves in an eccentric way.

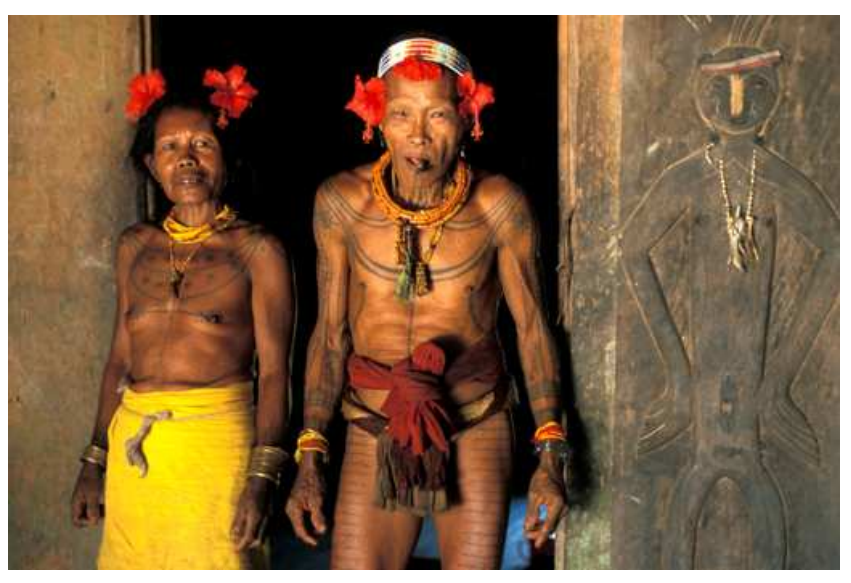

Figure 7. Elderly Mentawai couple Source: Remi Benali Photographer.

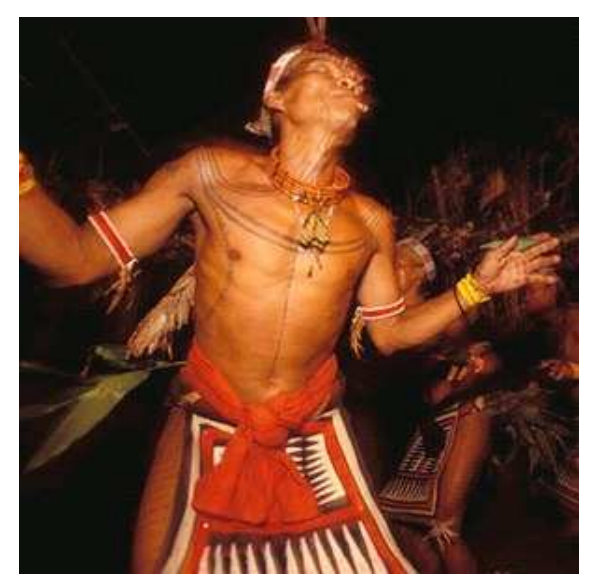

Figure 8. Mentawai shaman dancing Source: http://www.eso-garden.com. 
The eccentricity of the shaman is accepted or even welcome because it contributes to the well being of all. The shaman heals individuals and advises the community - sometimes politically - but is at the same time placed outside the system of responsibility and formal power, outside the world where chieftains and priests decree the rules. The aged person as shaman represents an element of counter-power. This opens the possibility to enter history as 'the great shaman'. The name of the 'great shaman' goes from mouth to mouth, surviving from generation to generation. Ageing becomes an extraordinary chance to rise to a new level of performance and existence.

What is particular with the shaman model of ageing is the otherness of old age, i.e. the perspective of another identity and new growth following parental and working life. By this new identity, the elderly person appears not only as an object of health care, but primarily as a healer. Under health aspects, the aged is not - or not only - a burden, but primarily a resource. Cultural bodily activity thus enters into an alternative understanding of health: the shaman not only dances for himself or herself, the elderly as shaman dances 'for all'.

Anyways, the otherness of the shaman is a cultural construction. In our eyes, it may be eccentric and an expression of craziness, even if we do not follow the earlier anthropological discourse about the 'fraudulent witchdoctor'. The case calls to our attention that normalization is a cultural construction, too. In a shamanic society, the shaman is normal.

Further: Every young is an elderly of tomorrow. In this respect, ageing is not (only or primarily) the problem of a particular group in society, but an existential challenge for all.

A similar relativity of the normal body can be found for the case of children and youth. This can be seen in Western history. Paintings of noble children from the eighteenth century display a body we would never see today. The normality of that time would nowadays be extremely abnormal (For the following see also Korsgaard 1982).

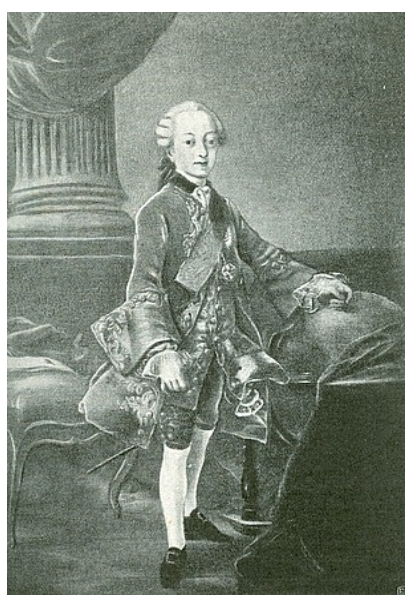

Figure 9. The young Christian VII of Denmark

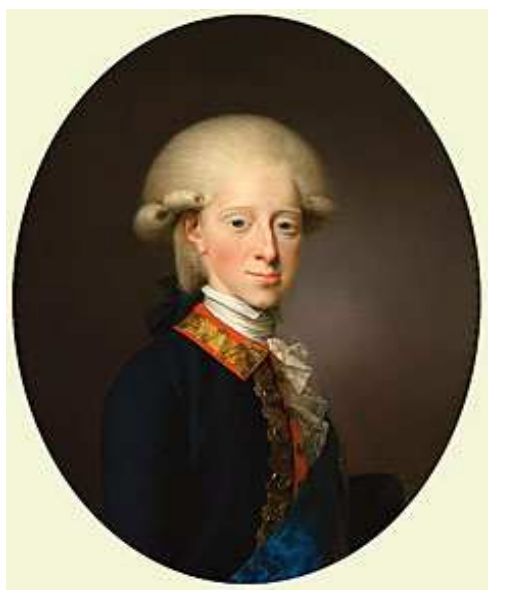

Figure 10. The young Frederik VI of Denmark, painted by Jens Juel Source: http://www.danskhistorie.dk.

Christian VII of Denmark (1749-1808) as child shows the normal body display of his time - from the powdered wig over the stiff clothes down to the foot stance, the so-called dance master posture (Figure 9). The staging of the aristocratic child has its logic in a society marked by violence and by distinction from the

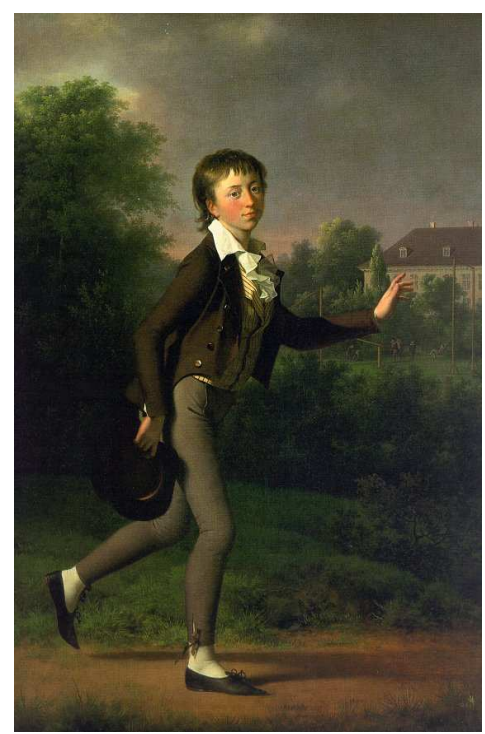

Figure 11. Running boy, painted by Jens Juel in 1802

Source: Statens Museum for Kunst, Copenhagen. Also Korsgaard 1982, p. 33. 'rabble'. There was built up a configuration of social discipline, of social geometry, which was represented by the so-called noble exercise - by minuet and other choreographic court dance, military exercises, dressage riding, and graceful epée fencing.

In 1784, we meet the same bodily display of Frederik VI (1768-1839) (Figure 10). 
And yet it took not even twenty years for the picture to fundamentally change. In 1802, the same artist - Jens Juel - delivered a painting of quite different character, one that showed an aristocratic boy of this time (Figure 11).

The display of the boy's hair, his tailcoat, the running habit, and the green environment - all seem to have changed. The popularity of the tailcoat had spread during the 1790s from English equestrianism, from the steeplechase as a new type of speed riding. And foot racing became an innovative educational exercise among the philanthropic schoolmen whose influence can be discovered by the gymnastic apparatuses in the background. There was no place any longer for the powdered wig. Instead, the stopwatch would represent the new type of 'normal' movement.

What is expressed in this simple bodily display is a new society, following the pattern of achievement, suspense and speed, or in other words: Performing, measuring, producing. The social geometry of the Age of Absolutism was replaced by the industrial configuration of streamlining the body, with "career" and "progress" as iconological concepts and sport as their ritual.

Seen with eyes from nowadays, we recognize a - revolutionary - shift towards the specific type of modernity, which we now would recognize as normal, in spite of all differences in detail. Normality had changed.

A résumé of anthropological comparison and historical change in relation to biology can reveal

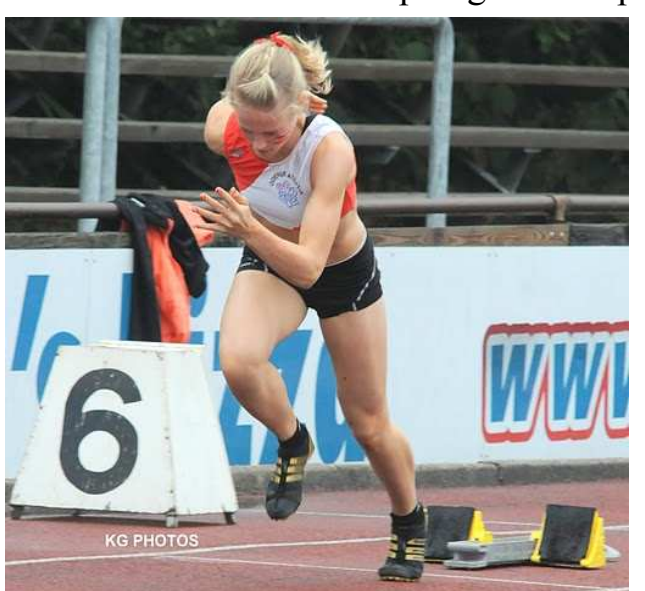

Figure 12. Young Danish athlete two different disciplinary approaches to normality and otherness - natural sciences and cultural studies. In the centre of biology stands the reconstruction of human normality, aiming at a diagnosis of abnormality and disability - and striving for rehabilitation. In the centre of cultural studies, by contrast, we find normalities in plural, revealed by comparison and analysis of historical change. In the world of modern health care, these other normalities are represented by the self-organization of patients, by client organizations of the 'disabled', as well as by the meeting of different cultures of health and different cultures of the body.

\section{Theory of democracy: normality and power}

With a closer look, however, the cultural and social study reveals different social approaches to normality, too. The one is seen from above. In a panoptical perspective, normality is homogeneity, uniformity, and unity. Michel Foucault (1975) described this in his studies about the panopticon and the panoptic 'microphysics of power', which have developed since 1800.

Seen from below, the picture is different. There is difference, diversity, distinction - and the quest for recognition.

Normality and the construction of otherness are related to power. This is why it is eye-opening to include the theory of democracy. Let us have a look at the aspects of sovereignty and equality.

Sovereignty is crucial for the understanding of political subjects: Who is the sovereign? The dominant theory of sovereignty has its roots in Absolutism, following the line of Niccolo Machiavelli, Jean Bodin, and Thomas Hobbes. Jean Bodin, a French Catholic jurist and political philosopher, expressed in his Les six livres de la République (1576) the classical understanding of sovereignty as "la puissance absolue et perpetuelle d'une Republique", the absolute and persistent power of a republic. This resulted in a consequent top-down understanding: "The sovereign Prince is only accountable to God." The practical background of this concept was the presence of religious civil war in Europe. That is why one could conclude: Better tyranny than anarchy. 
This was connected with a particular organization of the body. At the top, there was the splendor of power. Louis XIV of France (1638-1715) represented "L'État, c'est moi" - I am the state.

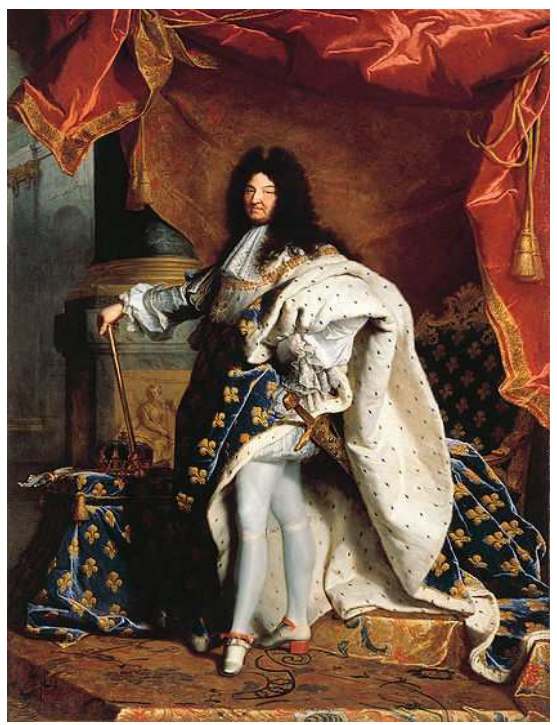

Figure 13. Louis XIV. of France in royal dress

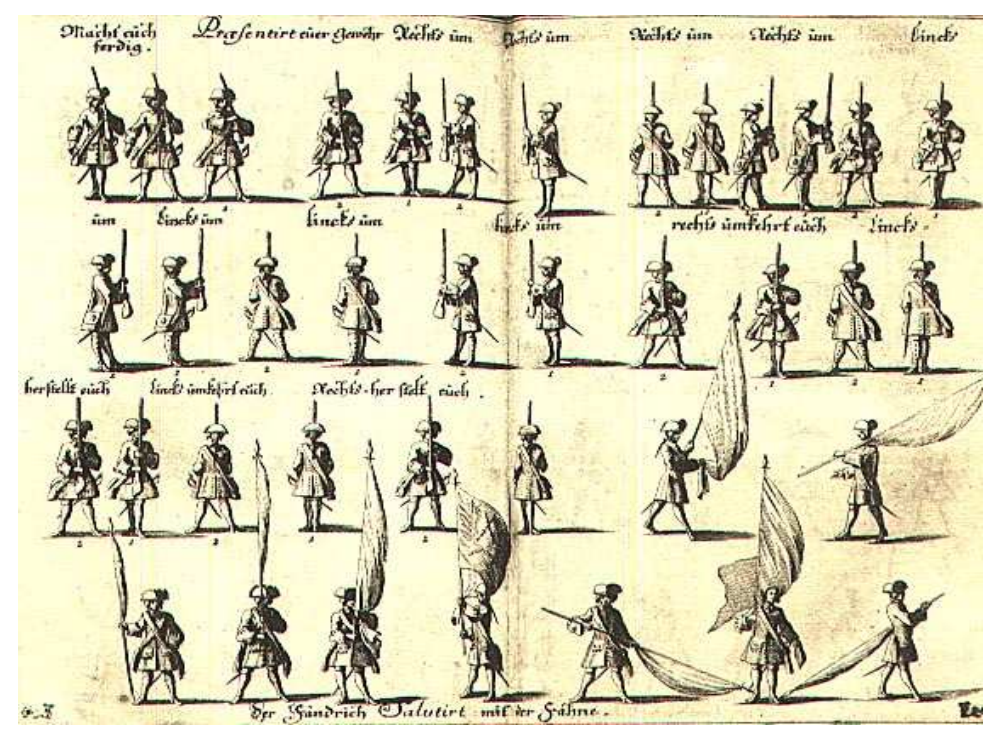

Figure 14. Exercises of the Saxon army, $18^{\text {th }}$ century Source: http://www.pib-11.de/lager/lager1730.html.

On the level of the people, the sixteenth and seventeenth centuries brought a new formation of the military body. The normalization of exercise in rank and file became a fundamental pattern of social-geometrical character. The ancient Roman term of disciplina was redefined and applied as social discipline in bodily terms.

The top-down discipline of state sovereignty was, however, not without alternatives. With the background of the Dutch revolution against the Spanish crown, Johannes Althusius, a German Calvinist jurist and political philosopher, developed a contrasting concept (Hueglin, 1999). In his Politica (1603), society was described as a multitude of consociations, of families, guilds, corporations, university colleges, towns, and provinces. Human beings joined together in these social units acting with reciprocity, mutuality and solidarity, and building sociality as federation (foedus). Sovereignty was located in all these federations and consociations of the people, and it could only

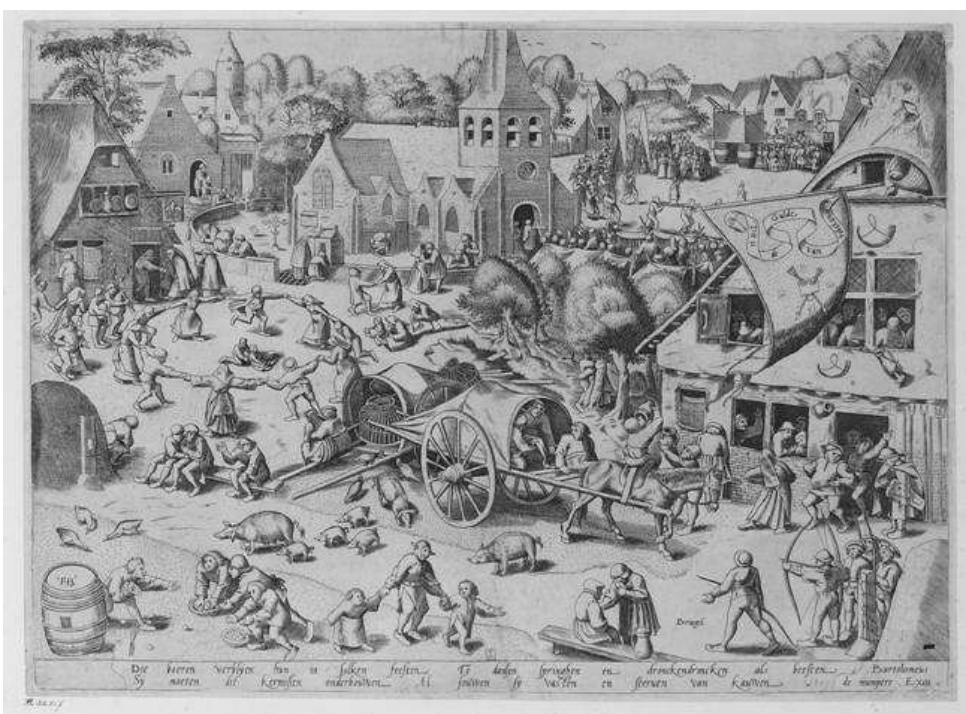
temporally be administrated by a monarch. Sovereignty was, and has always remained, bottom-up. The sovereign was the people, and so sovereignty could fundamentally not be delegated.

This concept, which was both traditionalist and revolutionary, had a bodily correlation, too. It may be seen in the pictures of Dutch folk life. Pieter Bruegel gave a depiction of popular dance, play and games in his copper-stick of the Fair at Hoboken, 1559 (Figure 15).

Figure 15. Fair at Hoboken, copper-stick of Pieter Bruegel, 1559

Source: http://www.pib-11.de/lager/lager1730.html.

However, this bottom-up understanding of sovereignty was held for a long time by the minority. Much later, Jean Jacques Rousseau transferred the Althusian anti-despotic idea to the modern concept of the 'sovereignty of the people', shifting, however, the basis from the associational civil life to the individual. This revealed revolutionary qualities during the French revolution and the building of 
modern democracy. The fundamental bottom-up dynamics of associational life and diversity were rediscovered in the twentieth century, first by the German Jewish philosopher Martin Buber, and then by recent studies of civil society, underlining the associational aspect of self-determination and habitual difference. Civil society means that everybody is another for others. And everybody is part of a minority.

Corresponding to the contradiction between top-down and bottom-up sovereignty, equality, which became a basic value of modern democracy, is differentiated, too. On one hand, equality can be understood as a high degree of uniformity - all should substantially be equal. On the other hand, equality means the recognition of difference - people should be equal in their rights and choices to be different.

\section{Theory of sports: differences of otherness - and the sumo body}

If applied to the theory of sports, the relation between sameness and otherness reveals that the contradiction between top-down and bottom-up is more than a question of ideas and values - they are a question of body and movement. And, it is too complex to be understood in a dualistic pattern. In modern sport and body culture, one meets at least three different patterns of how to relate one's own exercising body to the other (About the trialectics of the modern body culture see Eichberg 1998 and 2004).

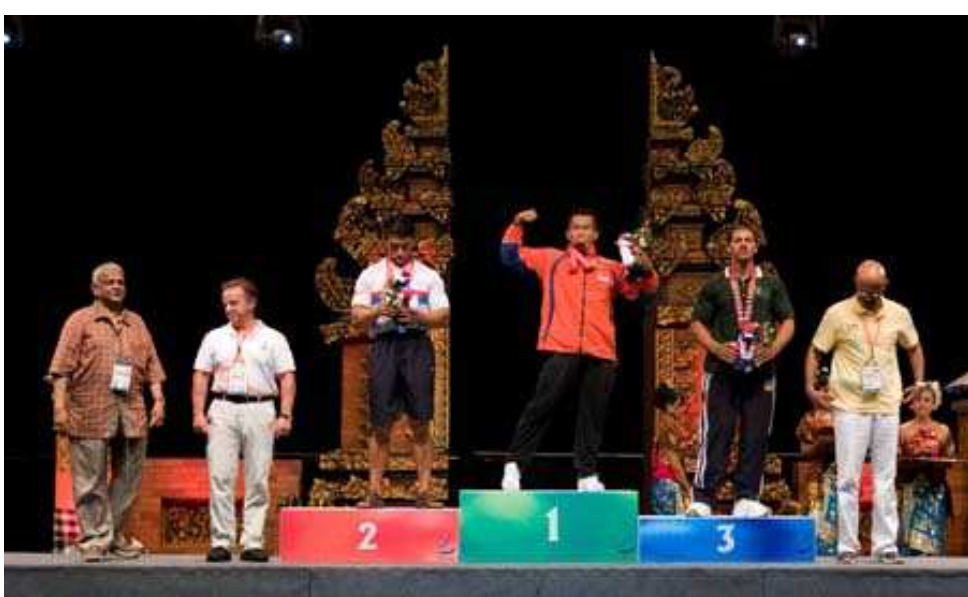

Figure 16. Olympic winner ceremony, Beijing 2008

Source: http://www.zimbio.com.
Competitive sport streamlines the body and teaches one to keep the rules of competition. It homogenizes and normalizes the human being by adapting the individual to the body technique of winning and producing results. In the hierarchical order of competitive sport, the place for otherness is 'down there', where the declassified losers are huddled together in their misery. All are united in striving for achievement and excellence, but some are better, and some are worse. This is what the

first model of sport signifies, turning otherness into a pyramidal order.

Another model, one developed by exercise and gymnastics, works on the integration of the individual into the social system, on discipline and adaptation. Being relatively egalitarian, the model of discipline is effectuated by choreographic body formation, typically in straight lines, in rank and file. Individual movements are synchronized, often on the command of a leader. Authoritarian physical discipline and body control does not favour difference, deviation or dissent. In fact, more often than not, it explicitly

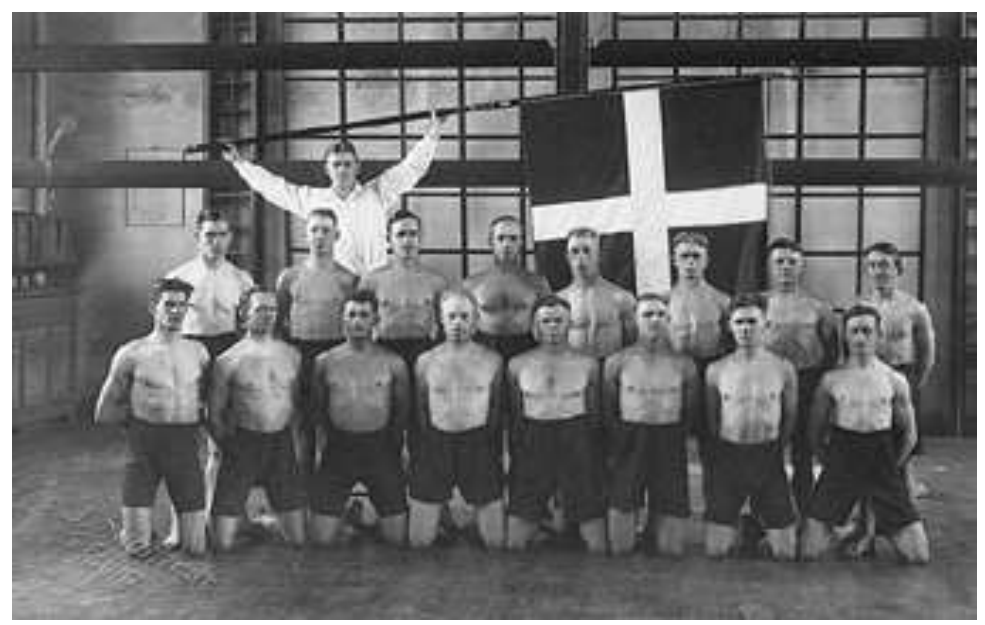

Figure 17. Danish gymnastics in the Niels Bukh style, 1920/30s Source: Kolding Kommune. http://www.kolding.dk. 
suppresses them, by correction according to a given rule. Sports of discipline and integration treat otherness by 'normalizing', and thus eliminating, it.

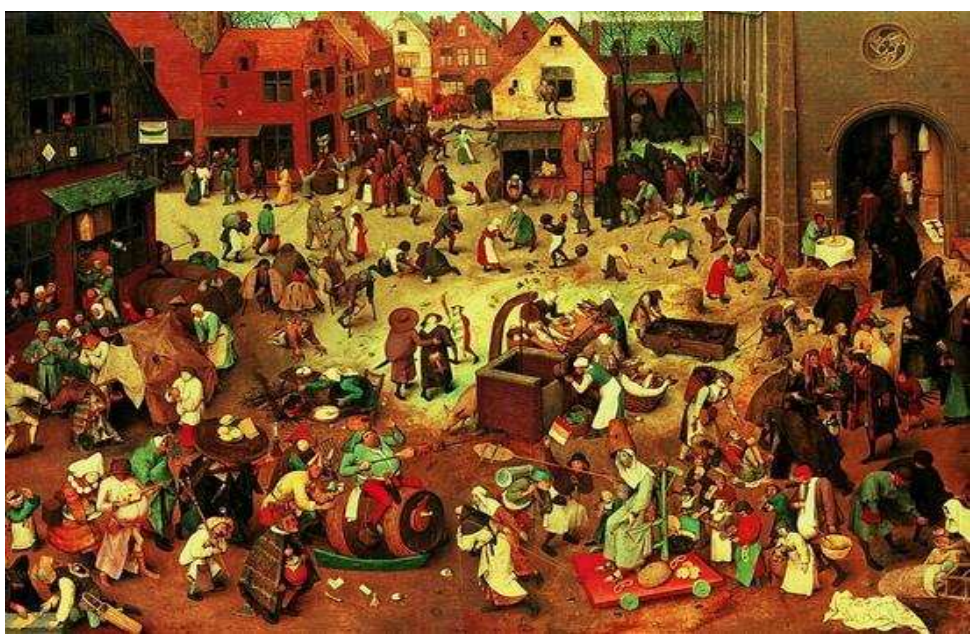

Figure 18. The Battle between Carnival and Lent, painting by Pieter Bruegel, 1559
Both models thus give priority to the production of sameness. They classify every movement into 'the correct' versus 'the incorrect', whether by means of competition or by rules of discipline.

Popular movement culture as a third model contrasts itself through a display of diversity. In popular festivity, people meet otherness as irreducible difference. The nonpanoptical order of folkelig festivity makes surveillance impossible, otherwise the festive event would just be a 'show'. In festivity and play, otherness meets otherness. People build relations, simulate 'other' identities with masks, and display their own identity as alterity. Everybody is another for others. The carnival has delivered a picture for this, as in Pieter Bruegel's 1559 painting.

As seen in the tension between these patterns, there is revealed what we can call the trialectics of body culture. Sport is not one. In modern sports, at least three different normalities are important. The diversity of sports tells a deeper story about the relation to the other.

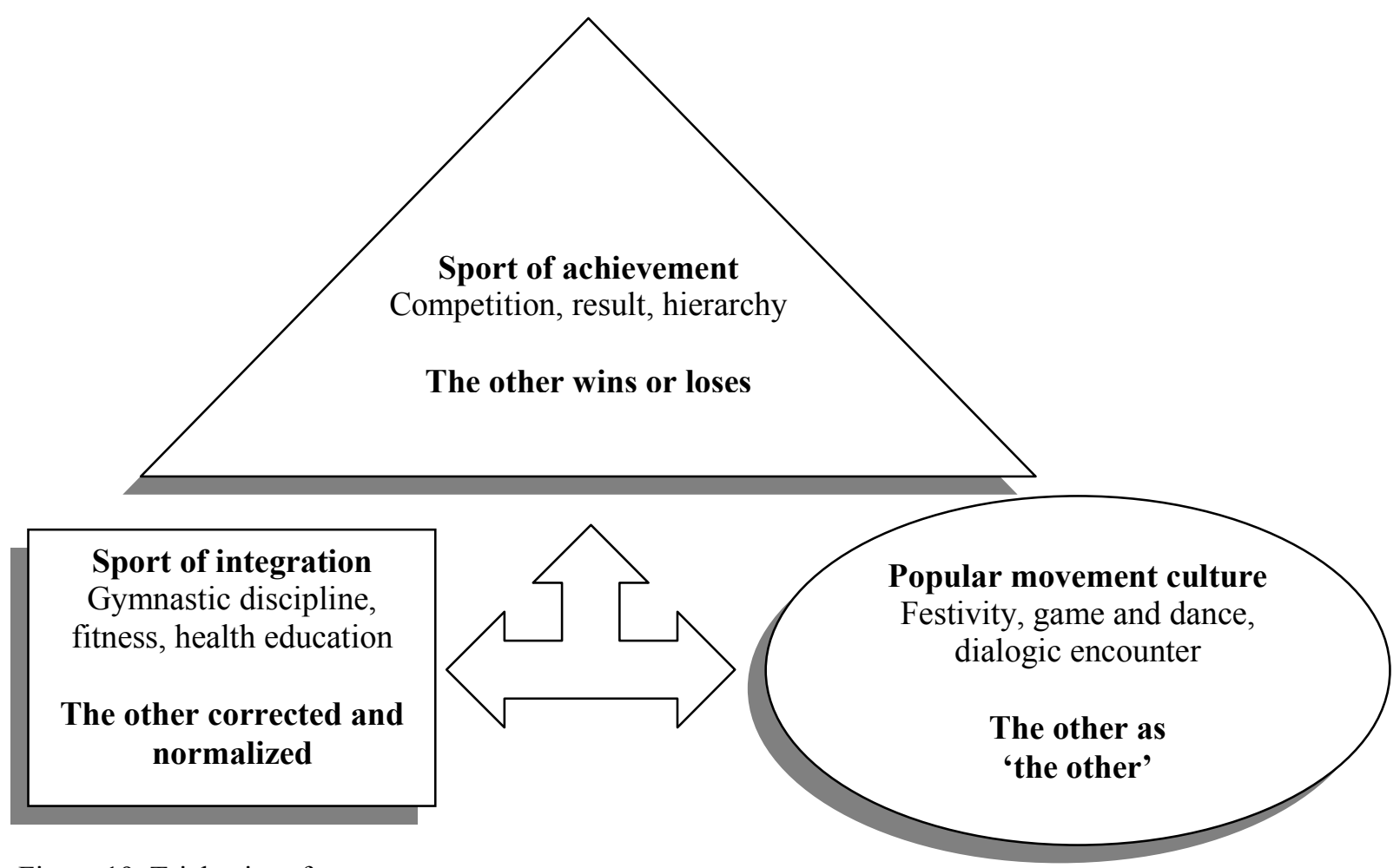

Figure 19. Trialectics of sports

Source: Kolding Kommune. http://www.kolding.dk.

\section{Sumo, politics of recognition and the relativity of the body}

If everybody is another for others, and if everybody is part of a minority, the question arises, what this may mean for the treatment of 'others' as minority groups. However, the analysis of 
normalization and otherness in culture does not directly instruct the observer what to do. And yet, it enriches our fancy and imagination about how cultures do treat and can treat normality and otherness. There is no simple bridge from 'how it is' to 'thou shall', but there is an opening towards potentiality: 'See, how it can be!'

Japanese sumo wrestling can be understood as a case, how bodily diversity and 'deviance' can be cultivated in the form of the extraordinary (Möller 1990, 1994, Newton, Toff 1994, Guttmann, Thompson 2001, pp. 13-26, 108-15, 181-88).

The body of the sumo wrestler is far from the 'normal' Japanese body (Figure 20). According to the ideal norm, the Japanese man is slim and dressed in a dark suit of Western style. In contrast to this rather uniform norm, however, the human body can also be fat, huge and even grotesque, even in Japan. While some societies try to prevent a deviation from the 'normal' slim shape by advanced cultural techniques, as in Western fitness culture, Japanese popular culture has, by sumo, opened a way for the 'other' body. The huge body is dressed in colourful garment and placed into a world of particular ceremonies. Thus, the sumo wrestler has become a national hero and is displayed as such, while definitely not being a national body model.

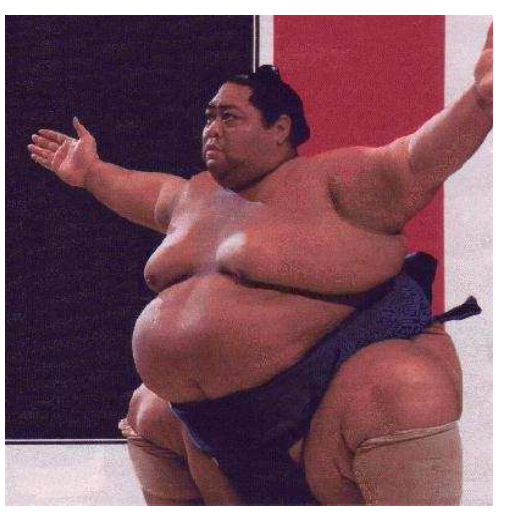

Figure 20. Body of a sumo wrestler Source: http://www.paperstone.co. uk.



Figure 21. Sumo in Japanese woodcut, early $19^{\text {th }}$ century Source: http://japan.so01one.com.

The otherness of the sumo body is cultivated especially by elaborate ritual movements - by dance-like movements, the casting of rice, the ceremonial opening of a fight, the ritual display of humility, and the fighter's submission to the referee.

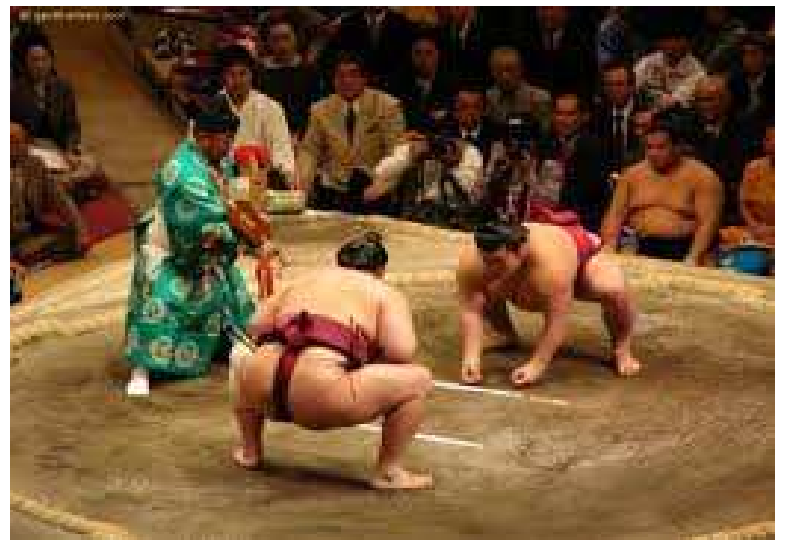

Figure 22. Sumo referee and wrestlers in ritual display Source: http://www.tokyoezine.com.



Figure 23. Sumo wrestling exhibition at Yasukuni shrine, Tokyo

Source: http://www.zimbio.com.

Ritual and Shinto ceremonies show that sumo wrestlers by their bodily otherness are 'messengers of God'. Here, they can be seen at the annual sumo-wrestling exhibition at the Yasukuni shrine in Tokyo in 2010. 
In contrast to the streamlining national body politics of disciplinary gymnastics, and in contrast to the international standardizing body image of Olympism, movement culture can thus value the eccentricity of bodily otherness. It can express by bodily means that everybody is other to others (Concerning the eccentricity of 'the other body' in Japanese culture in pictures, see Inagaki 1988).

This is where democracy may meet sports: the critique of normality. The recognition of otherness is confronted with the striving for normalization and sameness. Radical democracy has its bodily basis in a culture of both equality and diversity. This is - and remains - a contradiction. For tackling this contradiction, there does not exist one perfect solution. We might wish for easy answers, especially under the current conditions where veils are regulated and the burka prescribed or forbidden, where exclusions are demanded in relation to skin color and religious denominations, where minorities are hassled for the sake of normalization. And yet, the politics of recognition remain an open challenge, defining how society is organized.

But knowledge helps lead towards deeper understanding by opening up the relativity of the 'normal' body. Knowledge develops between culture and culture, between otherness and otherness. Normality in terms of biology, as well as otherness in the terms of cultural studies, have to enter into critical dialogue with each other. The dialogue is about the contradiction between statistical normality on one hand and the human potentials on the other hand, which can be found in any single cultural case with its own normality - in normalities as a plural of otherness. This is the challenge of interdisciplinary exchange.

\section{REFERENCES}

Eichberg, H. (1998). Body Cultures. Essays on Sport, Space and Identity. London, New York: Routledge.

Eichberg, H. (2004). The People of Democracy: Understanding Self-Determination on the Basis of Body and Movement. Århus Klim.

Eichberg, H. (2010). Sports in the Life Cycle: Diversity in and of Ageing. In Bodily Democracy: Towards a Philosophy of Sport for All. London: Routledge.

Foucault, M. (1975). Surveiller et punir. La naissance de la prison. Paris: Gallimard. - In English: Discipline and Punishment. Harmondsworth: Penguin.

Guttmann, A. \& Thompson, L. (2001). Japanese Sports: A History. Honolulu: University of Hawaii Press.

Hueglin, T. O. (1999). Early Modern Concepts for a Late Modern World: Althusius on Community and Federalism. Waterloo, Ontario: Wilfrid Laurier University Press.

Inagaki, S. (1988). A Japanese collection of pictures about the grotesque body.

Jespersen, E. \& McNamee, M. (2008). Philosophy, adapted physical activity and disability. Sport, Ethics and Philosophy, 2(2), 87-96.

Korsgaard, O. (1982). Kampen om kroppen. Dansk idrcets historie gennem 200 år. (Struggle about the body: 200 years of Danish sport history.). Copenhagen: Gyldendal.

Lindsay, C. \& Schefold, R. (1992). Mentawai Shaman - Keeper of the Rain Forest. Man, Nature, and Spirits in Remote Indonesia. New York: Aperture.

Möller, J. (1990). Sumo - Kampf und Kult. Historische und religiöse Aspekte des japanischen Ringens. Sank Augustin: Academia.

Möller, J. (Ed.) (1994). Sumo. München: Iudicium-Verlag.

Newton, C. \& Toff, G. J. (1994). Dynamic Sumo. Tokyo: Kodansha International.

Povlsen, J. (2000). Representations of the body in old age - cultural and social change. In J. Hansen \& N. Kayser Nielsen (Eds.), Sports, Body and Health. Odense: Odense University Press.

AUTHOR'S ADDRESS: Henning Eichberg University of Southern Denmark Institute of Sport Science, Campusvej 55

DK-5230 Odense M, Denmark

Email: heichberg@health.sdu.dk 